\author{
Abstracta Iranica \\ Abstracta Iranica Revue bibliographique pour le domaine irano-aryen \\ Volume 37-38-39 | 2018 \\ Comptes rendus des publications de 2014-2016
}

\title{
Anthony Eastmond (ed.). Viewing Inscriptions in the Late Antique and Medieval World
}

\section{Iván Szántó}

\section{(2) OpenEdition}

1 Journals

\section{Electronic version}

URL: http://journals.openedition.org/abstractairanica/42735

DOI: 10.4000/abstractairanica.42735

ISBN: 1961-960X

ISSN: 1961-960X

Publisher:

CNRS (UMR 7528 Mondes iraniens et indiens), Éditions de l'IFRI

Electronic reference

Iván Szántó, «Anthony Eastmond (ed.). Viewing Inscriptions in the Late Antique and Medieval World », Abstracta Iranica [Online], Volume 37-38-39 | 2018, document 2, Online since 10 March 2018, connection on 26 September 2020. URL : http://journals.openedition.org/abstractairanica/42735 ; DOI : https://doi.org/10.4000/abstractairanica.42735

This text was automatically generated on 26 September 2020

Tous droits réservés 


\title{
Anthony Eastmond (ed.). Viewing Inscriptions in the Late Antique and Medieval World
}

\author{
Iván Szántó
}

\section{REFERENCES}

Anthony Eastmond (ed.). Viewing Inscriptions in the Late Antique and Medieval World, Cambridge \& New York: Cambridge University Press, 2015, 261 p. ISBN: 9781107092419

1 Iran is not the primary interest of this book, yet nearly each of its eleven essays bear some degree of significance for Iranian studies, thus each will be briefly mentioned. As set out by the editor in the introduction, the volume focuses on the often-overlooked non-textual matters conveyed by epigraphy, which range from the multilingualism of inscriptions and their audiences, to the legibility, accessibility, materiality, and performativity of monumental texts.

The only article dealing with Iran is the first one, by Matthew Canepa, which is also where the most ancient texts are discussed in this chronologically-arranged volume ("Inscriptions, Royal Spaces and Iranian Identity: Epigraphic Practices in Persia and the Ancient Iranian World", pp. 10-35). Canepa observes that there is an underlying sense of continuity linking the inscriptions of ancient Iran, the strength of which becoming all the more striking if considered that the makers of the later monuments were almost certainly unable to read the vestiges left by their predecessors. The author goes on to explain this enduring tradition by pointing to the permanence of rock-carved inscriptions in an otherwise unstable political landscape, which may have compelled later rulers to repeat inherited ritual formulae and practices without being aware of the actual content of ancient texts, and such repetitive acts could become part and parcel of the customs of Iranian kingship throughout the ages. 
3 Ann Marie Yasin's essay analyses early Christian graffiti across the Mediterranean between Campania and Syria as a means for devotees to mark their direct encounters with the holy and perpetuate their prayers ("Prayers on Site: The Materiality of Devotional Graffiti and the Production of Early Christian Sacred Space”, pp. 36-60). In his study about the erasure of the patron's name from Aghlabid inscriptions by the Aghlabids' Fatimid successors, Jonathan M. Bloom points out that this intervention of the new dynasty was not simply an application of the principle of damnatio memoriae, for the supposedly permanent effacement of a name became a constant reminder of its bearer's unlawful acts (chapter 3, pp. 61-75). Anthony Eastmond argues that carved inscriptions on the façades of Georgian churches datable to ca. 1000 CE (e.g., Kumurdo, Ishkhani, Parkhali cathedrals) are textual equivalents of icons, as suggested by their sculptural articulation and strategical placement (chapter 4, pp. 76-98). The appearance of pseudo-Arabic "inscriptions" on Byzantine architecture, especially the monastery of Hosios Loukas ( $c a .961 \mathrm{CE}$ ) conveyed, according to Alicia Walker, the sense of pilgrimage for visitors by alluding to the real Arabic inscriptions of the Holy Land and their talismanic sanctity (chapter 5, pp. 99-123). Although the Arabic inscriptions in the Cappella Palatina in Palermo (ca. 1143 CE), built for the Norman kings of Sicily, are real, their purpose was likewise not informative but performative: they asserted the king's knowledge of (though not his literacy in) Arabic and, by extension, his allpowerfulness, as demonstrated by Jeremy Johns, with reference to the trilingual and even quadrilingual inscriptions of Norman Sicily (chapter 6, pp. 124-147). Very similar notions characterise the multilingual tomb inscription of Castilian king Ferdinand III (r. 1217-1252) in the cathedral of Seville where the inclusion of Arabic may have been included not in a demonstration of religious tolerance, but rather, in Tom Nickson's interpretation, to testify the king's supreme sagacity which far surpassed the linguistic skills of his subjects (chapter 8, pp.170-186). Scott Redford contextualises the inscriptions outside and inside the Karatay Madrasa at Konya (ca. $1251 \mathrm{CE}$ ) by pointing out that their script style, placement, and utterances follow a hierarchic order which reflects the gradual revelation of divine knowledge for students during their actual training process in the religious school (chapter 7, pp. 148-169). Ioanna Rapti's study about the $14^{\text {th }}$-century inscriptions in the monastery of Noravank brings us to the rarely visited topic of Il-khanid Armenia which the religious eclecticism of the Mongol Empire seems to have permeated (chapter 9, pp. 187-204). In the last article of the volume, following an essay about $14^{\text {th }}$-century epigraphs in the cathedral of Genoa (pp. 205-229), Sheila S. Blair discusses authorship in Islamic art by bringing together craftsmen's signatures from a wide range of objects (from ivory caskets to paintings) and a vast temporal and chronological horizon and analysing their placement on the artworks, as well as the scripts and epithets they use ("Place, Space and Style: Craftsmen's Signatures in Medieval Islamic Art”, pp. 230-248). 


\section{AUTHORS}

IVÁN SZÁNTÓ

Eötvös Loránd University, Budapest \& Austrian Academy of Sciences, Vienne 